Humaniora. Czasopismo Internetowe

$\mathrm{Nr} 2(34) / 2021$, ss. $13-30$

\author{
MAŁGORZATA JANKOWSKA \\ Uniwersytet im. Adama Mickiewicza w Poznaniu \\ Instytut Kulturoznawstwa \\ e-mail: helga82@amu.edu.pl \\ ORCID: 0000-0002-6568-6475 \\ DOI: https://doi.org/10.14746/h.2021.2.1
}

\title{
Kulturoznawcze badanie intertekstualnych gier z kanonem. Propozycje teoretyczno-metodologiczne
}

\begin{abstract}
The role the canon plays in culture will be discussed in the paper. The canon can be seen as one of the most important media of cultural memory, a kind of cultural grammar or a vital semantic resource which influences a huge amount of new texts. This sort of textual variations on the canon may be considered secondary cultural mnemotechniques; in the same way intertextuality may be interpreted as a tool of active remembering. From the perspective of the semiotics of culture the above-mentioned canon-based hypertexts serve not only as memory-devices but as examples of cultural autocommunication as well. While religion as one of the most crucial „cultural systems” (Geertz) influences a lot of other subsystems of the semiosphere (Lotman), intertextual relations to the canon of religious texts vitalize the hypotext and create the whole set of new meanings, strengthening semiosis and dynamizing culture at the same time.
\end{abstract}

Keywords: canon, intertextuality, semiotics of culture, cultural memory, symbol, religion

\footnotetext{
Celem artykułu jest przedstawienie poznawczych potencjałów i ograniczeń kulturoznawczego namysłu nad kanonem oraz nad intertekstualnymi doń nawiązaniami. Chodzi zatem o takie rozumienie wspomnianego kanonu oraz rzeczonych nawiązań, które pozwoli na ich ogląd z perspektywy szerszych mechanizmów kultury, a więc również na wyjście poza horyzonty stricte religioznawcze czy literaturoznawcze, przy jednoczesnym częściowo aprobatywnym do nich podejściu.
} 
Zacząć oczywiście trzeba od umiejscowienia religii w szerokim polu kultury, a dalej wskazać należy na możliwe sposoby kulturoznawczego oglądu tytułowych tekstów kanonicznych, sytuujących się w jej centrum. Dookreślenia wymaga samo rozumienie „kulturoznawczego oglądu”. Podkreślić więc należy, że kulturoznawstwo pozostaje zbiorem teorii i metod, a prezentowane tu ujęcie jest tylko jednym z wielu możliwych. Wyznaczać je będzie semiotyka kultury, przede wszystkim spod znaku szkoły tartusko-moskiewskiej, wraz z semiotycznie zorientowaną antropologią w wydaniu Clifforda Geertza i w połączeniu z wybranymi ideami wytworzonymi w polu badań nad pamięcią kulturową. Poniższy szkic ma charakter z konieczności skrótowy i syntetyczny, a także stricte teoretyczny ${ }^{1}$.

\section{Kultura i religia}

Na mocy tak zwanej Ustawy 2.0. i związanych z nią rozporządzeń oficjalnie z polskiego horyzontu naukowego zniknęło wiele z uznanych dyscyplin o pewnych ugruntowanych już tradycjach, ramach teoretycznych i metodologiach, w zamian zaś powstały inne, w założeniu łączące poprzednie. Tym sposobem na polskiej akademickiej mapie pojawiła się dyscyplina o nazwie „nauki o kulturze i religii”, mająca zastąpić czy zespolić w jedno między innymi kulturoznawstwo, antropologię kulturową i religioznawstwo. Nazwa nowej dyscypliny może wprowadzać w lekkie zakłopotanie, występująca w niej bowiem koniunkcja sugeruje osobność zespolonych z nią „bytów”, gdy tymczasem oczywiste jest, iż religia jest (niezwykle zresztą istotną) częścią kultury, stanowiąc tym samym przedmiot zainteresowania między innymi wspomnianego już kulturoznawstwa² (choć jednocześnie - nie wszystkich kulturoznawców, kierujących swoją uwagę również w stronę innych zjawisk), a także antropologów kultury. Religia nie jest zatem jakimś oddzielonym od kultury bytem, lecz stanowi jej integralną część, zarówno wpływając na inne jej systemy, jak choćby sztuka, literatura czy polityka (by wskazać tylko niektóre), jak i sama ulegając wpływom³ ${ }^{3}$ Nawet po sproblema-

${ }^{1}$ Szczegółowe analizy wybranych intertekstualnych gier z kanonem przeprowadziłam w książce Żywotność kanonu. Semiotyka współczesnej apokryficzności (Wydawnictwo Nauk Społecznych i Humanistycznych UAM, Poznań 2019). Tam też pogłębionemu oglądowi poddaję pojęcie kanonu, a także wprowadzam szeroki kontekst teoretyczny i metodologiczny na podstawie ustaleń semiotyki kultury.

${ }^{2}$ Co nie oznacza, że marginalizować należy historię i dokonania religioznawstwa - pragnę jedynie wskazać na fakt, że z punktu widzenia nauk o kulturze, kulturoznawstwa i antropologii kulturowej religia jest istotną częścią kultury, a tym samym pozostaje przedmiotem zainteresowania tych nauk, co bynajmniej nie unieważnia namysłu nad nią prowadzonego z innych perspektyw teoretycznych i metodologicznych.

${ }^{3}$ Przykładem mogą być chociażby relacje między systemem religii i systemem nauki, a konkretnie jednym z podsystemów tego drugiego, mianowicie - z historią. Tak zwane „trzy poszukiwania Jezusa historycznego" stanowią doskonałe egzemplum przepływu komunikatów 
tyzowanych przez Maxa Webera „odczarowaniach świata”, jako umiejscowiona w przestrzeni kultury symbolicznej (czy przekonań symboliczno-kulturowych, by użyć sformułowania Jerzego Kmityª), pełni religia liczne funkcje społeczno-regulacyjne, pozostając jednocześnie, by użyć bardziej semiotycznych pojęć, rezerwuarem nośnych kulturowo znaczeń i symboli, a tym samym pozostając ściśle związaną również z aspektami pamięciowymi, jako nośnik (i zarazem przedmiot) pamięci kulturowej/zbiorowej. Rozpatrywać ją więc można (czy wręcz - należy) z punktu widzenia tak jej „,semantyki”, jak i aspektów wielowymiarowo „pragmatycznych” (między innymi pod kątem wielopoziomowych „aktów komunikacji” czy właśnie jej wspomnianego regulatywnego w stosunku do kultury czy wspólnoty charakteru).

Jak zatem badać można religię z kulturoznawczego punktu widzenia? W ujęciu semiotycznym postrzegać ją można właśnie jako wspomniany system kultury. Oczywiste jest, że takie podejście wymusza dookreślenie samej kultury, a dopiero w dalszej kolejności umiejscowienie w jej obrębie wspomnianego systemu.

Tym, co łączy rozmaite koncepcje i podejścia semiotyczne, jest podstawowa kategoria znaczenia, a dalej kwestia jego umiejscowienia, to jest dążenie do ustalenia tego, w jakim kontekście czy w jakiej przestrzeni znaczenie (czy raczej - znaczenia) są wytwarzane, przetwarzane, komunikowane etc. To właśnie tu pojawia się wspomniana konieczność doprecyzowania pojęcia kultury.

Jednym z możliwych ujęć semiotycznych (a raczej hermeneutyczno-semiotycznych) jest proponowane przez Clifforda Geertza rozumienie kultury jako sieci znaczeń. Amerykański antropolog wprost wskazuje na inspirację Maksem Weberem:

Będąc, wraz z Maksem Weberem, przekonanym, że człowiek jest zwierzęciem zawieszonym w sieciach znaczenia, które sam utkał, kulturę postrzegam właśnie jako owe sieci, jej analizę traktuję zaś nie jako eksperymentalną naukę, której celem jest odkrywanie praw, lecz jako naukę interpretatywną, która za cel stawia sobie odkrycie znaczenia ${ }^{5}$.

Inaczej jeszcze rzecz ujmując, kultura to „uosobiony w symbolach, przekazywany z pokolenia na pokolenie wzorzec znaczeń, system dziedziczonych koncepcji, wyobrażanych w formach symbolicznych, za pomocą których ludzie

\footnotetext{
między wspomnianym przestrzeniami, dalej asymilacji i przekładu tychże komunikatów, o czym szerzej pisałam w książce Żywotność kanonu. Semiotyka współczesnej apokryficzności, w podrozdziale Pogranicza, przepływy, translacje, przekodowania. Jezus historii a Chrystus wiary, ss. 188-217. Por także: M. Skierkowski, Apologia Jezusa historycznego. Kilka uwag metodologicznych, „Znak” 2009, nr 647, http://www.miesiecznik.znak.com.pl/6452008ks-marek-skierko wskiapologia-jezusa-historycznego-kilka-uwag-metodologicznych/ [dostęp: 12.02.2017].

${ }^{4}$ Por. między innymi: J. Kmita, Późny wnuk filozofii. Wprowadzenie do kulturoznawstwa, Bogucki. Wydawnictwo Naukowe, Poznań 2007, ss. 93-94.

${ }^{5}$ C. Geertz, Opis gęsty: w poszukiwaniu interpretatywnej teorii kultury, w: idem, Interpretacja kultur. Wybrane eseje, tłum. M.P. Piechaczek, Wydawnictwo Uniwersytetu Jagiellońskiego, Kraków 2005, s. 19.
} 
komunikują, utrwalają i rozwijają swą wiedzę o życiu i swe życiowe postawy”6 (przy czym podkreślić należy, że „dziedziczenie” wiąże się tu z procesami enkulturacji, a nie dziedziczeniem w sensie biologicznym ${ }^{7}$ ). Kultura to zatem owe wspomniane sieci znaczeń, nieustannie wytwarzanych, cyrkulujących, używanych. To sieci o charakterze, jak to określa antropolog, publicznym i społecznym, zastane przez jednostki ${ }^{8}$, wobec których kultura pełni swoistą funkcję kontrolną ${ }^{9}$. Semiotyka kultury oparta na tym ujęciu to nie tylko system deszyfracji, ale i opis oraz interpretacja „kulturowych idiomów” czy „nośników myśli”, przy uwzględnieniu zarówno tego, co w kulturze statyczne, jak i tego, co dynamiczne, a więc zachodzących w niej zmian, zwrotów, kryzysów czy rewolucji. Geertz umiejscawia religię w tym szerokim kontekście, rozumiejąc ją, w skrócie, jako wspomniany powyżej system kulturowy, a szczegółowo definiując jako „(1) system symboli, (2) budujących w ludziach mocne, wszechogarniające i trwałe nastroje i motywacje (3) poprzez formułowanie koncepcji ogólnego ładu istnienia i (4) tworzenie wokół tych koncepcji takiej aury faktyczności, że (5) owe nastroje i motywacje wydają się niezwykle rzeczywiste” ${ }^{10}$. Badacz, odnosząc się do rozróżnienia na „model czegoś” i „model dla”, stwierdza następnie, że religia, jak i wszelkie wzorce kulturowe, pełni funkcję podwójną, realizując się w obu ze wspomnianych typów: nadaje znaczenie rzeczywistości społecznej, zarazem przystosowując ją do siebie, jak i przystosowując się do niej ${ }^{11}$. Geertza zatem interesuje to, co określa on jako „kulturowy wymiar analizy religii”"12, a eksploracja tego wymiaru zasadzać się ma właśnie na ujęciu semiotycznym czy też hermeneutyczno-semiotycznym ${ }^{13}$.

${ }^{6}$ C. Geertz, Religia jako system kulturowy, w: idem, Interpretacja kultur..., s. 111.

7 „Jeśli chodzi o wzorce, czyli systemy lub zespoły symboli, to najistotniejszym dla nas ich charakterystycznym rysem jest to, że stanowią one zewnętrzne źródła informacji. Mówiąc »zewnętrzne«, mam na myśli jedynie to, że - w odróżnieniu od, dajmy na to, genów - leżą one poza granicami jednostkowego organizmu w tym intersubiektywnym świecie wspólnych znaczeń, w którym jednostki ludzkie się rodzą, przeżywają swoje indywidualne życie i który trwa nadal po ich śmierci”. C. Geertz, Religia jako system kulturowy, s. 114.

${ }^{8}$ Por. C. Geertz, Wpływ koncepcji kultury na koncepcję człowieka, w: idem, Interpretacja kultur..., zwłaszcza ss. 63-64.

9 „Kultura, postrzegana jako zestaw symbolicznych narzędzi służących do kontrolowania zachowania, pozasomatycznych źródeł informacji, staje się elementem łączącym to, czym ludzie, dzięki temu, co daje im natura, są w stanie się stać, a tym, czym każdy z nich po kolei w rzeczywistości się staje. Stawanie się człowiekiem oznacza stawanie się indywidualną jednostką, a ową indywidualność zdobywamy, idąc za wskazówkami wzorów kulturowych, stwarzanych przez historię systemów znaczenia, w oparciu o które nadajemy naszemu życiu kształt, ład, sens i kierunek. Wzorce kulturowe, o których tutaj mowa, nie są zaś wzorcami ogólnymi, lecz konkretnymi [...]”. C. Geertz, Wpływ koncepcji kultury..., s. 71.

${ }^{10}$ C. Geertz, Religia jako system kulturowy, s. 112.

${ }^{11}$ Ibidem, s. 115.

12 Ibidem, s. 111.

13 Jak pisze w innym miejscu przytaczanego tekstu: „Jeśli Langer ma rację, twierdząc, że "pojęcie 'znaczenia', we wszystkich swych odmianach, jest dominującym pojęciem naszych czasów«, że »znak, symbol, denotacja, znaczenie, komunikacja [...] tworzą nasze [intelektualne] 
Jednocześnie ujęcie semiotyczne nie może dla Geertza być pozbawione wyraźnego odniesienia do praktyk i wartości, stąd umieszcza on religię w sferze połączenia „etosu i światopoglądu” ${ }^{4}$. Nie rozwija on w pełni tej myśli, przywołać tu jednak można definicję proponowaną przez Kmitę, który w pewnym (acz nie zupełnie ścisłym, co sam podkreśla) duchu diltheyowskim ujmuje światopogląd jako „system przekonań, które określają w trybie normatywnym wartości »ostateczne» (niesłużące już żadnym innym wartościom), a zarazem prezentują obraz świata ukazujący, jak się mają poszczególne jego fragmenty, zwłaszcza nasze działania, do tych wartości »ostatecznych«; czy podporządkowane są im aksjologicznie jako wartościom pozytywnym, czy podporządkowane są ich negacjom (aksjologicznym), czy wreszcie są pod tym względem neutralne”15. Wracając jednak do Geertza - w jego ujęciu religia winna być badana dwuetapowo: w pierwszej fazie jako system znaczeń i symboli (wymiar semantyczny), w drugiej jako system odnoszący się do procesów społeczno-strukturalnych i psychologicznych ${ }^{16}$ (aspekt pragmatyczny, normatywny, społeczno-regulacyjny, w tym również odniesienie do wspomnianego światopoglądu).

Innym możliwym ujęciem semiotycznym jest zaproponowana przez współzałożyciela tartusko-moskiewskiej szkoły semiotyki kultury, Jurija Łotmana, koncepcja semiosfery. Jest to „niepodzielny działający mechanizm”, jednostka semiozy, „cała właściwa danej kulturze przestrzeń semiotyczna”, która jest „zarówno rezultatem, jak i warunkiem rozwoju kultury”17, i poza którą nie istnieje ani język, ani komunikacja. W semiosferze funkcjonuje mnogość języków, tekstów i podsystemów. Łotman podkreśla, że jest ona realnością semiotyczną, a od innych semiosfer lub tego, co z jej wnętrza postrzegane jest jako „niesemiotyczne” (a co w istocie jest na ogół przestrzenią właśnie innych semiosfer), oddziela ją granica o pewnej określonej przepustowości, która zarazem dzieli, jak i łączy, to bowiem miejsce przepływu komunikatów, przestrzeń translacji, wymiany, komunikacji ${ }^{18}$. Wspomniane granice semiosfery, ich ulokowanie, wynikają z jej samoopisu, który pojawia się w momencie osiągnięcia przez nią wysokiego stopnia złożoności. Są one również konstruowane każdorazowo przez badacza, który w swych analizach

oprzyrządowanie«, to być może nadszedł już czas, by antropologia społeczna, a zwłaszcza ta jej część, która zajmuje się badaniem religii, zdała sobie sprawę z tego faktu”. C. Geertz, Religia jako system kulturowy, s. 111.

${ }^{14}$ Por. ibidem, s. 111 i 134.

15 J. Kmita, Miejsce światopoglqadu w kulturze, w: J. Kmita, Późny wnuk filozofii..., s. 90.

${ }^{16}$ C. Geertz, Religia jako system kulturowy, s. 146.

17 J. Łotman, Uniwersum umysłu. Semiotyczna teoria kultury, tłum. B. Żyłko, Wydawnictwo Uniwersytetu Gdańskiego, Gdańsk 2008, s. 199.

${ }^{18}$ Dokładnej problematyzacji pojęcia semiosfery dokonuje Łotman między innymi w drugiej części książki Uniwersum umysłu. Semiotyczna teoria kultury (część druga, Semiosfera, ss. 197-313) oraz w tekście O semiosferze, w tomie Kultura, historia, literatura, tłum. B. Żyłko, Wydawnictwo Uniwersytetu Gdańskiego, Gdańsk 2017, ss. 93-113. 
nakreśla interesujący go horyzont namysłu ${ }^{19}-\mathrm{w}$ tym sensie opis semiosfery ma charakter retoryczny, jednak nie stoi to w opozycji do, uwypuklanej przez Łotmana, wspomnianej już realności semiosfery. W kategoriach semiosfery rozumiane mogą być zatem różne przestrzenie czy systemy, o różnym stopniu złożoności - zarówno kultura, jak i cywilizacja, a także poszczególne ich podsystemy.

Łotmana interesuje taki ogląd semiosfery, który bierze pod uwagę zarówno wymiar synchroniczny, jak i diachroniczny, zarówno jej statykę, jak i dynamikę. Do tego, co w danej semiosferze statyczne, trwałe, stałe zalicza badacz między innymi przestrzeń religii ze stojącymi w jej centrum symbolami. Nie znaczy to, że w przestrzeni tej nie ma miejsca na zmiany czy przesunięcia, a więc na wspomnianą dynamikę - Łotmanowi chodzi tu jednak przede wszystkim o mnemotechniczny i tożsamościowotwórczy charakter owych symboli. Kultura bowiem to, w optyce tak Jurija Łotmana, jak i Borisa Uspienskiego - innego wpływowego przedstawiciela szkoły tartusko-moskiewskiej, również „niedziedziczna pamięć społeczeństwa”20. Z poziomu metaoglądu semiosfera może się jawić jako spójna przestrzeń o wspomnianych granicach, oddzielających ją od innych semiosfer, w rzeczywistości jednak, jak podkreśla Łotman, poprzedzielana jest mnogością wewnętrznych granic przebiegających między jej rozmaitymi podsystemami, między wypełniającymi ją językami etc. Zachodzą między nimi procesy wymiany, translacji, mariażu czy konfliktu, co wewnętrznie dynamizuje tak całą semiosferę, jak i owe jej podsystemy. Religię można widzieć jako jeden z takich właśnie podsystemów, łącząc w ten sposób intuicje semiotyczne Geertza z ideami Łotmanowskimi, i przy podkreśleniu właśnie jej źródłowego dla danej semiosfery charakteru (jej zasoby symboliczne mogą być widziane, ze wskazanych powyżej perspektyw, jako rezerwuary tego, co „statyczne”, gdyż właśnie „źródłowe”).

\section{Symbole i teksty. Religia jako rezerwuar zasobów semiotycznych}

Łotman, by powtórzyć, szczególną wagę przywiązuje do symboli, będących dlań nośnikami pamięci kulturowej. Badacz podkreśla zresztą, że żaden system semiotyczny bez koncepcji symbolu obejść się nie może. Rozumie on symbol dość „ogólnie”, jako „ideę pewnej treści, która służy jako plan wyrażenia dla innej, z reguły kulturowo cenniejszej, treści”"21, wskazuje jednak na jego cechy dystynktywne, które odróżniają go chociażby od znaku, i które decydują o jego swoistości. Badacz stwierdza zatem, że symbol (1) pozostaje zamkniętym, określonym

${ }^{19}$ A jeśli funkcjonuje on w odnośnej semiosferze, to jego działania wpisują się również $\mathrm{w}$ jej procesy samoopisowe.

${ }^{20}$ J. Łotman, B. Uspienski, O semiotycznym mechanizmie kultury, tłum. J. Faryno, w: Semiotyka kultury, red. E. Janus, M.R. Mayenowa, PIW, Warszawa 1977, s. 150.

${ }^{21}$ J. Łotman, Uniwersum umysłu..., s. 182. 
tekstem tak w planie treści, jak i wyrażania, co pozwala z łatwością wydobyć go z otoczenia semiotycznego, dostrzec go, wraz z jego granicami, pośród rozmaitych znaków czy tekstów, nawet w bardzo złożonym kontekście. Nadto, zdaniem Łotmana, symbol zawsze (2) zawiera w sobie pewien „pierwiastek archaiczny”, niosąc w skondensowanej postaci całą mnogość złożonych, istotnych kulturowo treści ${ }^{22}$, co sprawia, że pełni on nad wyraz ważną rolę w tworzeniu i pielęgnowaniu tożsamości kulturowej, stanowiąc de facto (3) medium pamięci, bowiem „nigdy nie należy do jakiegoś jednego synchronicznego przekroju kultury - zawsze przeszywa ten przekrój pionowo, przybywając z przeszłości i odchodząc w przyszłość. Pamięć symbolu jest zawsze starsza niż pamięć jego niesymbolicznego tekstowego otoczenia”23. Jako wspomniany nośnik istotnych informacji i swoiste „narzędzie mnemotechniczne”, (4) symbol potrafi wchodzić w nowe konteksty, nowe semiotyczne otoczenie, i budować w nim związki z innymi elementami (znakami, tekstami), nie tracąc przy tym swej znaczeniowej i strukturalnej autonomii. Związki te świadczą o jego (5) podwójnej naturze: z jednej strony jest on „posłańcem innych epok”, właśnie przypomnieniem o archaicznych korzeniach kultury, z drugiej jednak aktywnie funkcjonuje on w kulturze, w nowych przestrzeniach semiotycznych i otoczeniach tekstowych, zarazem transformując je, jak i samemu ulegając transformacji ${ }^{24}$.

Nakreślone przez Łotmana podstawowe, ogólne rozumienie symbolu, od którego zaczyna on jego pogłębioną analizę, koresponduje z ideami przywoływanego już Geertza, który podobnie rozumie symbol jako właśnie formę przedstawienia innej, z reguły cenniejszej kulturowo treści. Pisze więc, że „[są i tacy, którzy M.J.] posługują się pojęciem symbolu dla oznaczania wszelkich przedmiotów, aktów, zdarzeń, cech bądź relacji, które stają się nośnikiem jakiejś koncepcji [...] i takim właśnie ujęciem będę się [...] posługiwał”25. Następnie przywołuje on cyfry, krzyż i obrazy (jak Guernica) jako przykłady symbolu, dodając, że są to „namacalne przedstawienia pojęć, abstrakcje wypreparowane z doświadczenia i utrwalone w dostrzegalnych, widocznych formach, konkretne ucieleśnienia idei, postaw, sądów, tęsknot czy wierzeń”26. Jednocześnie, jako budulec tego, co antropolog określa mianem wzorców kulturowych, stanowią one, jak wspomniano już

22 Ibidem, s. 182.

23 Ibidem, ss. 182-183.

24 „Z jednej strony, przenikając złoża kultur, symbol realizuje się w swojej inwariantnej postaci. W tym aspekcie możemy obserwować jego powtarzalność. Symbol występować będzie jako coś niejednolitego w stosunku do otaczającej go przestrzeni tekstowej, jako posłaniec innych epok kulturowych (= innych kultur), jako przypomnienie o prastarych (= wiecznych) podstawach kultury. Z drugiej strony, symbol aktywnie koreluje z kontekstem kulturowym, transformuje się pod jego wpływem i sam go transformuje. Jego inwariantna istota realizuje się w wariantach. Właśnie w tych zmianach, którym ulega »wieczny« sens symbolu w danym kontekście kulturowym, kontekst ten najwyraźniej ujawnia swoją zmienność”. Ibidem, s. 183.

25 C. Geertz, Religia jako system kulturowy, s. 113.

26 Ibidem. 
wcześniej, zarówno „modele czegoś”, jak i „modele dla”, zarazem odzwierciedlają rzeczywistość kulturową, jak i ją kształtują, co podkreśla również Łotman w przywołanej już idei podwójnej natury symbolu.

Rezerwuarem wielu istotnych kulturowo symboli jest_system religii, przy czym wytwarzane na jego gruncie zasoby symboliczne z jednej strony otoczone są szczególną troską i szacunkiem, z drugiej zaś chętnie używane na różne sposoby, dywersyjne wobec ich kontekstu źródłowego, co z kolei rodzi wiele społecznych emocji, ale i pozwala dostrzec dynamikę kultury, jej niejednorodność, zachodzące w niej zmiany czy wręcz - rewolucje (gdzie semantyczne „przesunięcia” wywołują konsekwencje w obszarze pragmatycznym, komunikacyjnym, społecznym, kulturowym, ale też na odwrót - przemiany w tych obszarach skutkują nowymi podejściami do źródłowej symboliki).

Wspomniane symbole skumulowane są w świętych tekstach. Z tego względu semiotyka kultury, stawiająca tekst (obok znaku i symbolu) w centrum swojego zainteresowania, okazuje się ponownie płodną poznawczo perspektywą. Choć, jak zauważa Łotman, w swych początkach semiotyka, a w zasadzie semiologia (chodzi tu bowiem o myśl Ferdinanda de Saussure’a), zainteresowana była językiem, nie mową, czyli kodem, a nie tekstem, to jednak w kolejnych etapach rozwoju zainteresowała się ostatecznie także rozbudowanymi komunikatami.

Konieczność skierowania uwagi nie tylko na znak czy symbol, ale również na tekst, wynika między innymi z wielojęzyczności każdej kultury/semiosfery, a więc i z faktu, że każdy uczestnik komunikacji posługuje się wieloma kodami i że kody te nie zawsze się pokrywają, bowiem, gdy weźmie się pod uwagę „wpływ tradycji kulturalnej (semiotycznej pamięci kultury) i nieuchronną indywidualność, z jaką tradycja ta odsłania się danemu członkowi zbiorowości, to stanie się jasne, że nałożenie się kodów nadawcy i odbiorcy w rzeczywistości możliwe jest w pewnym bardzo względnym stopniu”27, a pełna przystawalność możliwa jest w zasadzie tylko w językach sztucznych, które z kolei pozbawione są ważnej funkcji języka naturalnego - funkcji twórczej. To dlatego każdy przekład tekstu z jednego języka na drugi czy z jednego systemu semiotycznego na inny ma charakter twórczy, pojawiają się naddatki sensu, a zawarte w danym tekście symbole ujawniają coraz to nowe potencjały semantyczne.

Tekst jest zatem zjawiskiem dynamicznym, będąc bowiem wielojęzycznym komunikatem, w akcie komunikacji (w odbiorze) zostaje zdekodowany w sposób twórczy. Nadto żyje on w swoich kolejnych odczytaniach, wpisując się w kulturową dialektykę statyki-dynamiki: z jednej strony, będąc kondensatorem pamięci (kolejna, obok twórczej oraz informacyjnej jego funkcja), musi zawierać elementy „statyczne”, z drugiej, by nie „skostnieć”, musi być używany, a historia jego użyć składa się właśnie na jego semiotyczne życie. Jak pisze Łotman:

\footnotetext{
27 J. Łotman, Uniwersum umysłu..., s. 71.
} 
[...] dla odbiorcy tekst jest zawsze metonimią rekonstruowanego znaczenia, dyskretnym znakiem niedyskretnej istoty. Suma kontekstów, w których dany tekst nabiera sensu i które w określony sposób są w nim inkorporowane, może być nazwana pamięcią tekstu. Ta stwarzana przez tekst przestrzeń semantyczna wstępuje w określone relacje z pamięcią kulturową (tradycją), spetryfikowaną w świadomości audytorium. W rezultacie te k s t znów zyskuje życie semiotyczne [podkreślenie M.J.] ${ }^{28}$.

Tekst zatem w kolejnych interpretacjach, odczytaniach czy adaptacjach, w nowych warunkach historycznych, w relacji do nowych ,nawiązujących doń tekstów rozwija swoje bogactwo semantyczne, zyskuje „życie semiotyczne”.

Jak wspomniano, w centrum systemu religii stoi często właśnie tekst, widziany z wewnątrz tego systemu jako święty, nienaruszalny, natchniony, od Boga pochodzący. Otaczany jest on szczególną czcią, a także w szczególny sposób odczytywany. W szerszym kontekście danego systemu kultury czy danej semiosfery centralny dla dominującej w rzeczonej semiosferze formacji religijnej tekst jest również „paradygmatem tekstu kulturowego”, jak określa to Aleida Assmann. Ta niemiecka badaczka pamięci kulturowej zainteresowana jest między innymi właśnie rolą tekstów w procesach zbiorowego upamiętniania. Przeprowadza ona podział na dwie formy pamięci - aktywną i bierną - a dalej przypisuje im dwie odmienne strategie „przechowywania tego, co dane do zachowania”, łącząc tym samym aktywne pamiętanie z kanonem, bierne zaś z archiwum. Interesuje ją szeroka perspektywa kulturoznawcza, stąd w równie szeroki sposób definiuje ona kanon. O ile dla innego badacza tego kręgu, Jana Assmanna, stanowi on nienaruszalny zbiór świętych tekstów ${ }^{29}$, o tyle dla Aleida Assmann - zbiór istotnych kulturowo tekstów o nie tylko sakralnym charakterze (włącza weń chociażby klasykę literatury, mitologię starożytnej Grecji, eposy etc., które J. Assmann wyraźnie od kanonu oddziela). Dla obojga badaczy kanon wiąże się, jak wspomniano, ze specyficznym, bo kulturowym trybem odbioru, nadto musi być nieustannie „w użyciu”, poddawany interpretacjom, egzegezom, kolejnym odczytaniom (choć z perspektywy wewnątrzreligijnej odczytania takie podlegają rozmaitym obostrzeniom, nierzadko również - zależy to od konkretnego systemu religii i konfesji, a także zrelatywizowane jest do czasu, miejsca i wspólnoty - winny być czynione wyłącznie przez „wyspecjalizowanych” strażników kanonu, zanurzonych w tradycji wcześniejszych odczytań, wzmocnionych autorytetem kapłańskim etc.). To właśnie ze względu na owo nieustanne „używanie”, a także korelowanie ze środowiskiem kulturowym, wspólnotą i czasem historycznym kanon funkcjonuje jako medium pamięci aktywnej, podczas gdy archiwum sytuuje się, jak sugeruje A. Assmann, w połowie drogi między kanonem a zapomnieniem. Archiwum to rezerwuar tekstów (ale i przedmiotów), które nie

28 Ibidem, ss. 77-78.

29 Por. J. Assmann, Pamięć kulturowa. Pismo, zapamiętywanie i polityczna tożsamość w cywilizacjach starożytnych, tłum. A. Kryczyńska-Pham, Wydawnictwa Uniwersytetu Warszawskiego, Warszawa 2008, ss. 118-143. 
są aktywnie używane, choć jednocześnie nie ulegają całkowitemu zapomnieniu, trwając w swoistej „gotowości do użycia”, mając zatem potencjał do stania się nośnikiem znaczeń ponownie aktualizowanych. Dla A. Assmann kanon to „lista tekstów uzasadniająca indywidualne kształcenie i kulturową tożsamość, a określana przez trzy wyznaczniki: wybór, wartość i trwanie”30. Pierwszy z nich wiąże się z odrzuceniem tego, co dla pamięci zbiorowej jest „nieobowiązkowe”31, przez co wpisany jest również w struktury władzy i potencjalne konflikty wewnątrzkulturowe czy społeczne, które rodzić się mogą w związku z kryteriami selekcji tekstów ${ }^{32}$ (problem reprezentowania/pomijania pewnych grup). Przypisanie wartości wiąże się z kolei z uświęceniem, to jest procesem przydawania swoistej aury tekstom włączonym do kanonu, ich uszlachetnieniem ${ }^{33}$ i umiejscowieniem najwyżej w hierarchii wszystkich tekstów. Kanon w rozumieniu A. Assmann nie jest wprawdzie tak „sztywny” jak ten w rozumieniu J. Assmanna, cechuje go jednak, mimo pewnej elastyczności, trwałość:

Kanon nie jest listą przebojów, jest natomiast niezależny od przemian historycznych i odporny na zmiany gustu społeczeństwa. Kolejne pokolenia nie muszą go samodzielnie ustanawiać - przeciwnie: to on trwa dłużej niż całe generacje, które wchodzą z nim w kontakt i muszą zreinterpretować go zgodnie z duchem czasu. Ta nieustanna interakcja (i niewielki wybór dzieł) zapewniają małym fragmentom przeszłości trwanie w ciągłej teraźniejszości ${ }^{34}$.

\section{Intertekstualne gry z kanonem}

Wspomniane „wchodzenie w kontakt” i interpretowanie zgodnie z duchem czasu zapewnia kanonowi żywotność, utrzymując go w centrum danej semiosfery - dzięki temu spełnia on funkcje wspólnototwórcze, tożsamościowotwórcze i „mnemotechniczne”, służąc jako medium pamięci kulturowej. To właśnie ta funkcja, oparta na wspomnianym już specyficznym trybie lektury, sprawia, że teksty przynależące do kanonu mają status tekstów kulturowych, które dla danej zbiorowości są „czymś więcej” niż po prostu teksty literackie ${ }^{35}$. Między oboma typami tekstów

${ }^{30}$ A. Assmann, Wprowadzenie do kulturoznawstwa. Podstawowe terminy, problemy, pytania, tłum. A. Artwińska, K. Różańska, Nauka i Innowacje, Poznań 2015, s. 321.

${ }^{31}$ Ibidem, s. 321.

${ }^{32}$ A. Assmann, Kanon i archiwum, tłum. A. Konarzewska, w: A. Assmann, Między historiq a pamięciq. Antologia, tłum. zbiorowe, red. nauk. i posł. M. Saryusz-Wolska, Wydawnictwa Uniwersytetu Warszawskiego, Warszawa 2013, s. 78.

33 Por. A. Assmann, Wprowadzenie do kulturoznawstwa..., s. 321, A. Assmann, Kanon i archiwum, ss. 78-79.

${ }^{34}$ A. Assmann, Kanon i archiwum, s. 78.

35 „Spoczywa na niej wymóg głoszenia ponadczasowej prawdy, połączonej z funkcją utwierdzania tożsamości zbiorowej; odwoływanie się do tego tekstu konstytuuje wspólnoty i odróżnia je od siebie. Sposób odczytywania Biblii jako tekstu kulturowego stanowi podstawę odróżnienia 
zauważyć można kilka różnic, które A. Assmann wyczerpująco analizuje ${ }^{36}$, wskazując między innymi na (1) związek tekstów kulturowych z tożsamością (lektura tekstu literackiego jest „lekturą prywatną”, samotną kontemplacją, podczas gdy lektura tekstu kulturowego jest lekturą przez pryzmat wspólnego dziedzictwa kulturowego, czytelnik jest zatem reprezentantem/członkiem pewnej formacji kulturowej), czy na (2) odmienne tryby odbioru (tekst literacki służy namysłowi, nauce lub rozrywce, a czytany jest z pewnego poznawczego dystansu, podczas gdy tekst kulturowy zakotwiczać ma czytającego w pewnej zbiorowości, a tę z kolei w historii lub w micie, czytany zaś jest z pozycji zaangażowania i swoistej czci). Tekst kulturowy ponadto (3) nie musi, w przeciwieństwie do tekstów „po prostu literackich”, „oddawać ducha czasu”, być innowacyjnym i nadążać za zmianami kulturowymi - wręcz przeciwnie, jako tekst formujący wspólnotową tożsamość musi być stabilny, trwały, opierać się wymogom „nowatorstwa”, a w końcu także być (4) ponadczasowy, gdyż, jak pisze A. Assmann, tekst stricte literacki „stoi w otwartej przestrzeni historii, kształtowanej przez prądy epoki, przełomy, mody i zmiany perspektywy”, tekst kulturowy natomiast „w zamkniętej przestrzeni tradycji, w której pojawia się wymóg niewyczerpanej i ciągłej aktualności oraz towarzyszy mu [...] decyzja, by trzymać się tego akurat tekstu, niezależnie od upływu czasu"37.

Zdaniem A. Assmann teksty kulturowe szczególnie ważką mnemotechniczną rolę odgrywają w kulturze, w której odnoszą się do tradycji dojrzałej, zarazem już „,ugruntowanej”, jak i wciąż aktualizowanej, czyli (re)interpretowanej i „używanej” w taki jednak sposób, by w procesie wydobywania nowych potencjałów znaczeniowych i kulturotwórczych nie następowała utrata sensów źródłowych - w ten sposób chroni się ona przed dezintegracją czy zapomnieniem ${ }^{38}$.

Rolę wspomnianej aktualizacji poprzez „użycia” i (re)interpretacje podkreśla również J. Assmann, który zauważa, że tekst (a także znak czy symbol), który nie podlega takim właśnie aktualizacjom, stopniowo ulega zapomnieniu czy petryfikacji, a tym samym traci swoją kulturotwórczą moc. Dlatego, zestawiając ze sobą dwie „kulturowe mnemotechniki”, to jest rytuał i tekst, stwierdza on, że to pierwsza z nich jest pewniejszą formą zbiorowego pamiętania, zasadza się bowiem na nieustannym powtórzeniu, a więc „użyciu”, „natomiast martwa litera tekstu istnieje materialnie również poza nią [cyrkulacją - M.J.] i łatwo może wyjść z obiegu. Kiedy zaś tekst wyjdzie z użycia, staje się raczej grobem niż skarbnicą

jej od innych tekstów. W przeciwieństwie do powieści przygodowych nie jest czytana dla relaksu ani rozrywki, ani też dla przeżycia katharsis, jej bohaterom natomiast przypisuje się znaczenie kosmologiczne i soteriologiczne. Będąc tekstem kulturowym, Biblia ma przywilej egzegezy, która uzupełnia tekst, nadaje mu aurę i wzbogaca sposób odczytania”. A. Assmann, Czym sq teksty kulturowe?, tłum. A. Konarzewska, w: A. Assmann, Między historiq a pamięciq..., s. 30.

${ }^{36}$ Ibidem, ss. 35-38.

37 Ibidem, s. 37.

${ }^{38}$ Ibidem, ss. 23-24. 
sensu, który wówczas może zmartwychwstać tylko dzięki wysiłkowi interpretatora, sztuce hermeneutyki i pośrednictwu komentarza”39.

Kulturowe życie kanonu oparte jest, jak wskazano, na jego licznych użyciach, przy czym nie muszą to być wyłącznie „użycia” wewnątrzreligijne, dokonywane przez jego „strażników” i ograniczone ramami danej ortodoksji. Nie muszą to być zatem - i w rzeczywistości nie są - wyłącznie oficjalne egzegezy, specjalistyczne teologiczne interpretacje, wyłącznie religijne odczytania. Życie semiotyczne kanonu zasadza się również na rozlicznych odczytaniach „nieortodoksyjnych”, niereligijnych czy nawet jawnie antyreligijnych, a także na przekładach intersemiotycznych, z języka kanonu (zarazem religijnego, jak i literackiego) na język sztuk wizualnych, na języki filozofii, polityki, filmu, muzyki etc.

Kanon może być widziany zarówno jako tekst, jak i jako kod - w zależności od ujęcia, rozmaite „wariacje” na jego temat i twórcze jego semiotyczne przekłady widziane być mogą bądź jako przekodowania tekstu źródłowego bądź jako nowe teksty opierające się na kodzie wyjściowym/kanonicznym. Łotman wyróżnia nadto dwa podstawowe modele komunikacji (tak w wymiarze jednostkowym/indywidualnym, jak i kulturowym) - model klasyczny, realizujący się w schemacie JA - ON, oraz model autokomunikacyjny, oparty na schemacie JA - JA. Semiotyk zaznacza jednocześnie, że w każdej kulturze obecne są oba z tych modeli, choć tylko jeden z nich dominuje ${ }^{40}$. Badacz stwierdza też, że „zewnętrzną komunikację buduje się według schematu: dany jest kod, wprowadza się tekst, który jest kodowany w jego systemie, a następnie przekazywany i wreszcie dekodowany”, natomiast „wewnętrzną komunikację buduje się według schematu: dany jest tekst, zakodowany w określonym systemie, wprowadzany jest drugi kod, tekst się transformuje. Kod stanowi zmienną, teksty na wejściu i wyjściu różnią się między sobą, przy czym następuje przyrost informacji w tekście dzięki jego współdziałaniu z nowym

39 J. Assmann, Pamięć kulturowa..., s. 106. Na kwestię tę zwraca również uwagę Paul Ricoeur, gdy, odnosząc się do uwagi Abellio o martwych symbolach zmieniających się po prostu w nazwy, pisze: „To jeszcze jedna przyczyna, dla której warto wykonywać pracę interpretacji, która nie ogranicza się do zwykłego rozwinięcia sensu, ale jest walką z możliwością upadku symbolu do rzędu obrazu, nazwy lub idola; dlatego musimy zawsze rozbijać stwardniałą skorupę symbolu, skamieniałego w ramach jakiejś kultury czy literatury, porzuconego jak martwa rzecz w świątyni, która służy zgodnie ze swym przeznaczeniem. Jest więc coś wadliwego w przekazie, w tradycji symbolu, co sprawia, że akt interpretacji to nie tylko akt pojmowania dokonany dla zrozumienia, ale także walka o życie symbolu, walka, by symbol przemówił, by pozwolić mu mówić. Oto dlaczego jedynym sposobem przyswojenia go sobie, uchwycenia go, jest interpretacja”. P. Ricoeur, Konflikt hermeneutyk: epistemologia interpretacji, tłum. J. Skoczylas, w: P. Ricoeur, Egzystencja i hermeneutyka. Rozprawy o metodzie, wybór i opracowanie S. Cichowicz, tłum. zbior., Pax, Warszawa 1985, s. 132.

${ }^{40}$ Modele komunikacji omawia Łotman szczegółowo w rozdziale Autokomunikacja: „„Ja” i „Inny” jako adresaci ( $O$ dwóch modelach komunikacji w systemie kultury) w przywoływanej tu już wielokrotnie książce Uniwersum umysłu..., ss. 79-97. 
kodem”41. Kultura/semiosfera jest, jak już wcześniej wskazano, przestrzenią polifoniczną i wielojęzyczną, funkcjonują w niej zatem rozliczne podsystemy i kody. Jeśli kanon potraktujemy jako tekst, dostrzeżemy w rozmaitych jego kulturowych użyciach coraz to nowe sposoby jego przekodowywania, z którym to procesem wiąże się z kolei przyrost informacji i naddatek sensów (to twórcza funkcja tekstu i zarazem twórcza funkcja przekładu - czy to z jednego języka naturalnego na inny, czy też z jednego systemu semiotycznego na drugi). Autokomunikację dzieli przy tym Łotman na dwa typy - mnemoniczny oraz inwencyjny, gdzie pierwszy nakierowany jest przede wszystkim na przechowanie informacji, drugi zaś na jej przyrost $^{42}$.

Odnosząc się do tego rozróżnienia, uznać można, że kanon służy zachowywaniu informacji jako między innymi „narzędzie mnemotechniczne” (choć jest to, z perspektywy religijnej, ujęcie w pewnej mierze redukcjonistyczne, podkreślmy jednak raz jeszcze, że chodzi tu o szerokie kulturowe rozumienie kanonu), jego egzegezy z kolei, a jeszcze bardziej - twórcze intertekstualne doń nawiązania - służą przyrostowi informacji i naddatkom sensu, a także dokumentacji różnorodnych przemian wewnątrzkulturowych. Jan Assmann wskazuje na trzy podstawowe typy nawiązań do kanonu - komentarz, naśladownictwo oraz krytykę, z kolei niemiecka teoretyczka literatury, Renate Lachmann, wyróżnia trzy podstawowe modele intertekstualności, które, gdy się przyjrzeć, w pewnej mierze pokrywają się ze strategiami przywołanymi przez badacza. Są to partycypacja, czyli kontynuacja pisania lub ponowne pisanie, tropika, czyli kontra-pisanie, oraz transformacja, czyli modyfikujące przepisywanie ${ }^{43}$, przy czym każde z nich wpisać można jednocześnie w obszar komentarza i naśladownictwa, tropikę zaś dodatkowo w przestrzeń krytyki. Z punktu widzenia przyrostu informacji oraz zachowywania tekstów źródłowych w centrum danej kultury, a więc i w pamięci, nawet odwracanie sensów pierwotnych, rewolucyjne czy subwersywne do nich podejście nie tylko wzmacnia kulturowe procesy autokomunikacyjne, ale ma także znaczące walory mnemotechniczne. Wydawać się wprawdzie może, że mocniej ugruntowują przekazy źródłowe te intertekstualne do nich nawiązania, które realizują strategię partycypacji, powtarzając je, naśladując i aprobatywnie odnosząc się do propagowanych w kanonie wartości. Warto jednak zauważyć, że poza aspektem „semantycznym” pod uwagę brać należy również wymiar pragmatyczny, komunikacyjny, z tego zaś punktu widzenia realizacje modeli tropiki czy nawet transformacji (a więc podejścia „wybiórczego” w stosunku do tekstu źródłowego,

${ }^{41} \mathrm{~J}$. Łotman, $O$ dwóch modelach komunikacji i ich wzajemnej relacji w ogólnym systemie kultury, w: J. Łotman, Kultura, historia..., s. 37.

${ }^{42}$ Por. ibidem, s. 38.

${ }^{43}$ R. Lachmann, Mnemotechnika i symulakrum, tłum. A. Pełka, w: Pamięć zbiorowa i kulturowa. Współczesna perspektywa niemiecka, red. M. Saryusz-Wolska, Universitas, Kraków 2009, s. 310. 
opartego również na mieszaniu elementów z różnych tradycji, kultur, mieszaniu różnych kodów i odmiennych zasobów semiotycznych) doskonale wpisują się w strategię zbiorowego pamiętania. Teksty tego typu pełnią funkcję szczególną nie tylko bowiem dynamizują semiosferę, nie tylko ilustrują i/lub prowokują różnorodne przemiany kulturowe, ale również, w wymiarze społecznym, wyzwalają silne emocje, prowokują dyskusje, i tym samym, ostatecznie, przykuwają uwagę na powrót do tekstu wyjściowego. Nawet bowiem uznając teksty kanoniczne, stojące w centrum danego systemu religii, za teksty kulturowe, nie sposób nie brać pod uwagę ich sakralnego charakteru - a tym samym kwestii tabu, uczuć religijnych, a także zjawisk takich jak profanacja czy bluźnierstwo. Szerokie rozumienie kanonu, takie, jakie proponuje nie tylko A. Assmann, ale też liczni literaturoznawcy ${ }^{44}$, pozwala „ominąć” te problemy, w zamian stawiając ewentualne kwestie smaku, stylu, innowacji, ścisłości relacji intertekstualnych między danym tekstem nowym a tekstem kanonicznym, problemy hermeneutyki etc. Jeśli jednak kanon rozumieć tak, jak czyni to J. Assmann, czyli jako nienaruszalny zbiór świętych tekstów, inny od zbioru klasyki (który to zbiór podciągany bywa pod pojęcie kanonu właśnie przez niemiecką badaczkę, jak i wspomnianych niektórych literaturoznawców), to zrozumieć można potencjalnie wybuchowy charakter intertekstualnych do niego nawiązań. Nierzadko zresztą społeczne emocje wywołuje nie tyle „zbezczeszczenie” świętego tekstu i sprzeniewierzenie się jego głównym sensom religijnym, ile naruszenie pewnej kulturowo sankcjonowanej „tradycji” obchodzenia się z nim, a także tradycji jego interpretacji, oraz, co szczególnie istotne, konstruowanej na podstawie konkretnych odczytań tożsamości zbiorowej (na przykład specyficznie rozumianej tradycji narodowej, sprzężonej z konkretną konfesją oraz z opartymi na zrelatywizowanych do tej wspólnoty i konfesji w danym czasie historycznym odczytaniami natchnionych tekstów, odczytaniami, dodajmy, które mogą znacząco różnić się od odczytań tego samego tekstu przez inne wspólnoty i/lub konfesje tego samego czasu historycznego). Obserwowanie społecznych reakcji na, widziane przez daną grupę jako obrazoburcze, odczytania tekstów kanonicznych stanowi ważny przyczynek do refleksji kulturoznawczej, szczególnie w sytuacji, gdy ujawnia wewnątrzkulturowe konflikty, zderzenia różnych światopoglądów funkcjonujących w tej samej semiosferze, różnych zatem systemów wartości czerpiących częściowo z tych samych podstawowych dla danej kultury zasobów symbolicznych.

Ciekawym przyczynkiem do refleksji nad różnymi kulturowymi sposobami odbioru tekstów opierających się na przekazie kanonicznym jest, wskazane już wcześniej, Łotmanowskie rozróżnienie na traktowanie przekazu w kategoriach tekstu i kodu. W jednym z klasycznych już tekstów szkoły tartusko-moskiewskiej, napisanym wraz z B. Uspienskim, Łotman tworzy szkicową „typologię” kultur, wyróżniając w niej te zorganizowane wokół planu treści oraz te zorientowane na

${ }^{44}$ Przykładowo na polskim gruncie czynią tak Danuta Szajnert czy Eliza Szybowicz. Szerzej na ten temat pisałam w książce Żywotność kanonu (głównie ss. 17-50). 
plan wyrażania. Te pierwsze w samoopisie jawią się jako zbiory reguł, te drugie zaś - jako zbiory tekstów. Pierwsze zorientowane są na kod, w opozycji do którego sytuują „niekulturę”. Dominującymi opozycjami są w tym modelu „porządek - chaos”, „kultura - natura”, „uporządkowany - nieuporządkowany”. Kultury tego typu są, zdaniem semiotyków, nastawione na rozwój, dynamikę, przyrost informacji i ekspansję, to bowiem, co nie jest kulturą, może w tej optyce się nią stać. Być może uznać można, że te intertekstualne nawiązania do kanonu, które bardziej „swobodnie” podchodzą do źródłowych komunikatów oraz ich sensów, postrzegają tekst wyjściowy raczej w kategoriach kodu, który służyć może do wytwarzania coraz to nowszych komunikatów (komunikatów, dodajmy, z konieczności wielojęzycznych, a więc operujących wieloma innymi jeszcze kodami, a także dekodowanych później w fazie odbioru za pomocą kolejnych jeszcze kodów). By przypomnieć, badacze w przywoływanym tekście ujmują kulturę jako pamięć, podkreślając zarazem jej ograniczoną pojemność (na co zresztą wskazują wszyscy teoretycy pamięci zbiorowej/kulturowej, nierzadko problematyzując zapomnienie jako swoistą „,higienę pamiętania”). O pamięci kultury decydują ich zdaniem dwa czynniki, to jest trwałość tekstów pamięci zbiorowej oraz trwałość kodu pamięci zbiorowej. Zarówno teksty, jak i kody są w każdej kulturze zhierarchizowane, przy czym najwyżej cenione i najbardziej mnemotechnicznie efektywne są teksty o „maksymalnej długowieczności” czy wręcz, jak określają je badacze, „panchroniczne”45, jeśli zaś chodzi o kody, to najwyżej w hierarchii plasują się te, które wykazują „zdolność do zmian przy równoczesnym zachowaniu pamięci o stanach poprzednich”46. W swobodnym podejściu do zasobów semiotycznych kanonu ujawniać się może, by powtórzyć, widzenie przekazu źródłowego w kategoriach właśnie kodu, do tego właśnie kodu na tyle elastycznego, by za jego pomocą wyrażać treści odmienne od wyjściowych, oryginalnych, a jednocześnie zachowującego wspomnianą „pamięć o stanach poprzednich”. Zorientowanie na kod może również wpływać na model odbioru intertekstualnych nawiązań do kanonu, na widzenie ich nie tyle w kategoriach „profanacji” czy „bluźnierstwa”, ile działania mechanizmów dynamizacji semiosfery, autokomunikacji, przyrostu informacji, naddatków sensu, przy jednoczesnym działaniu mnemotechnicznym. Być może zorientowanie na kod bliższe jest tym systemom, które żywią dystans do komunikatów źródłowych, gdzie teksty kanoniczne widziane są głównie (choć nie wyłącznie) jako teksty kulturowe, a więc w społeczeństwach zlaicyzowanych i kulturach nastawionych na zmianę (przy jednoczesnym, co należy podkreślić, ciągłym zorientowaniu na źródłowe zasoby symboliczne). Kanon jako kod zatem generuje mnogość nowych komunikatów, stając się rodzajem „kulturowej gramatyki”, niezbędnej do wyrażania treści kulturowych, ale traktowanej bardziej „instrumentalnie”. Ujawnia swoje kulturotwórcze moce w takich użyciach, jak

45 J. Łotman, B. Uspienski, O semiotycznym mechanizmie kultury, s. 152.

${ }^{46}$ Ibidem, s. 153. 
chociażby „obrazoburcze” powieści czy filmy, wykorzystywanie symboliki religijnej w sztuce, komiksie, reklamie, muzyce, polityce, twórczości internetowej (memy, pasty), akcjach społecznych, manifestacjach, w różnych rejestrach - od powagi, przez pastisze, karykatury, ironię, po ostrą, sięgającą po rozmaite środki retoryczne krytykę przekazów źródłowych.

Model zorganizowany wokół planu wyrażania z kolei realizowany jest przez te kultury, które postrzegają same siebie jako zbiory tekstów. W samoopisie kultura taka stoi w opozycji do antykultury, zatem nie, jak w modelu omówionym powyżej, chaos, natura, przestrzeń nieuporządkowania, lecz, jak to określają przywoływani badacze, „system o znaku ujemnym” stoi na jej „,antypodach”. Wynika to z tego, że podstawowa dychotomia, na której opierają się kultury tego typu, określana jest przez parę pojęć „prawidłowy - nieprawidłowy”. Z tego też względu „kultury planu wyrażania" skoncentrowane są na utrzymywaniu status quo, na strzeżeniu tego właśnie, co widziane jest przez nie jako „prawidłowe”, są mniej nastawione na dynamikę, i niezbyt ekspansywne, przestrzeń antykultury bowiem nie jawi się jako obszar możliwego rozprzestrzeniania się kultury, lecz raczej „zagrożenia” trwają one najczęściej w swoich określonych już granicach, pielęgnując to, co źródłowe ${ }^{47}$. Widzenie komunikatu źródłowego właśnie w kategoriach tekstu, do tego tekstu stojącego najwyżej w hierarchii, organizować może te intertekstualne doń nawiązania, które realizują przede wszystkim model partycypacji, a więc nierzadko naśladują, powtarzają i prze-pisują kanon, zachowując najważniejsze jego sensy, podchodząc zatem do jego zasobów symbolicznych z czcią i szacunkiem, a także z dużo mniejszą twórczą i semiotyczną swobodą niż te teksty, które oparte są na modelu tropiki czy transformacji. Również aspekt pragmatyczny, komunikacyjny, może być organizowany przez owo „tekstocentryczne” podejście - społeczny odbiór zbyt „swobodnych” czy „sprzeniewierzających się” kanonowi komunikatów doń nawiązujących może przyjmować charakter radykalnej krytyki i oburzenia jako reakcji na zetknięcie się z tym, co „nieprawidłowe” (na przykład „profanujące” czy „bluźniercze”). Odbiór taki może być organizowany przez widzenie kanonu przede wszystkim w charakterze „tekstu świętego”, nie kulturowego (lub - kulturowego niejako wtórnie, bo wciąż związanego z tożsamością danej zorganizowanej wokół niego formacji kulturowej czy zbiorowości).

Wspomniane typy kultur to modele, idealizacje, które skonceptualizowane zostały przez badaczy w ich mocno jeszcze strukturalistycznym okresie badań, kiedy matrycą czy wzorcem był język naturalny, określony jako pierwotny system modelujący, na jego wzór natomiast opisywano i badano wtórne systemy modelujące (podsystemy kultury). „Późny” Łotman odszedł od tej optyki w kierunku omówionego już pojęcia semiosfery, uznając wcześniejszą koncepcję modeli za wprawdzie heurystycznie płodną, ale nazbyt upraszczającą wobec złożonej i dynamicznej rzeczywistości kulturowej. Uznać chyba jednak można, że schematyczne,

47 Ibidem, s. 160. 
idealizacyjne rozróżnienie na dwa możliwe ujęcia tekstu - jako kodu i jako komunikatu, oraz równie idealizacyjne rozróżnienie na kultury planu treści i kultury planu wyrażania zachowują pewną moc objaśniającą, przy kilku zastrzeżeniach. Po pierwsze, kultury komunikują się zarówno w kanale JA - ON, czyli na zewnątrz, jak i w kanale JA - JA, czyli autokomunikują (choć w różnym stopniu), i w zależności od modelu komunikacji, na co wskazywał Łotman, zorientowane są bądź na tekst, bądź na kod. W danej kulturze ten sam kanoniczny komunikat może być traktowany na dwa sposoby. Po drugie, jak „późny Łotman” podkreśla wielokrotnie, kultura, choć zawiera w sobie „elementy statyczne”, wpisane w nią na stałe, wykazuje się również dynamiką, przy czym szczególnie dynamizujący charakter przyjmują wszelkie jej peryferia, skąd przychodzą do centrum innowacje, zmiany czy czasem wręcz „czynniki rewolucyjne” - w kulturze zatem funkcjonują zarówno obszary „zorientowania na kod”, przestrzenie dystansu do narracji źródłowych, do centralnych systemów (w tym systemu religii), jak i obszary „zorientowania na tekst”, przywiązania do tradycji, zaangażowania w przekazy źródłowe, nastawienia na „kulturową statykę”. Choć dana kultura może wykazywać się bardziej zorientowaniem na plan treści lub bardziej na plan wyrażania, nie jest tak, że drugi z planów nie jest w niej w ogóle obecny - nadto może być i tak, że panuje w tym względzie pewna równowaga sił, co prowadzi do wewnątrzkulturowych napięć.

Niezależnie od optyki (to jest zorientowania na kod/zorientowania na tekst) przekaz źródłowy, kanon, zdaje się funkcjonować w polu zainteresowania wspólnoty jako to, co statyczne w kulturze (niezależnie od tego, czy i jaki żywi ona dystans do jego sakralnego charakteru). Z perspektywy semiotyki kultury można uznać, że w rozlicznych intertekstualnych nawiązaniach kanon utwierdza swoją podwójną funkcję medium i zarazem przedmiotu pamięci kulturowej, niezależnie od trybu odbioru tychże nawiązań. Nie znaczy to, że aspekt semantyczny jawi się jako istotniejszy niż pragmatyczny, ten drugi jednak rozpatrywać można na różnych poziomach: idealizacyjnie na poziomie kulturowej funkcji autokomunikacyjnej (a więc także - tożsamościowotwórczej), a dalej na poziomie życia społecznego, czyli tak regulatywnego, normatywnego, jak i społecznych emocji. W końcu również oglądać można wspomniane życie semiotyczne kanonu z punktu widzenia dokumentacyjnego, widząc w intertekstualnych nawiązaniach do przekazu źródłowego przebłyski różnorodnych przemian kulturowych.

\section{Literatura}

Assmann A., Między historiq a pamięciq. Antologia, tłum. zbiorowe, red. nauk. i posł. M. Saryusz-Wolska, Wydawnictwa Uniwersytetu Warszawskiego, Warszawa 2013.

Assmann A., Wprowadzenie do kulturoznawstwa. Podstawowe terminy, problemy, pytania, tłum. A. Artwińska, K. Różańska, Nauka i Innowacje, Poznań 2015. 
Assmann J., Pamięć kulturowa. Pismo, zapamiętywanie i polityczna tożsamość w cywilizacjach starożytnych, tłum. A. Kryczyńska-Pham, Wydawnictwa Uniwersytetu Warszawskiego, Warszawa 2008.

Geertz C., Interpretacja kultur. Wybrane eseje, tłum. M.P. Piechaczek, Wydawnictwo Uniwersytetu Jagiellońskiego, Kraków 2005.

Jankowska M., Żywotność kanonu. Semiotyka współczesnej apokryficzności, Wydawnictwo Nauk Społecznych i Humanistycznych UAM, Poznań 2019.

Kmita J., Późny wnuk filozofii. Wprowadzenie do kulturoznawstwa, Bogucki. Wydawnictwo Naukowe, Poznań 2007.

Lachmann R., Mnemotechnika i symulakrum, tłum. A. Pełka, w: Pamięć zbiorowa i kulturowa. Współczesna perspektywa niemiecka, red. M. Saryusz-Wolska, Universitas, Kraków 2009.

Łotman J., Kultura, historia, literatura, tłum. B. Żyłko, Wydawnictwo Uniwersytetu Gdańskiego, Gdańsk 2017.

Łotman J., Uniwersum umysłu. Semiotyczna teoria kultury, tłum. B. Żyłko, Wydawnictwo Uniwersytetu Gdańskiego, Gdańsk 2008.

Łotman J., Uspienski B., O semiotycznym mechanizmie kultury, tłum. J. Faryno, w: Semiotyka kultury, red. E. Janus, M.R. Mayenowa, PIW, Warszawa 1977.

Ricoeur P., Egzystencja i hermeneutyka. Rozprawy o metodzie, wybór i opracowanie S. Cichowicz, tłum. zbior., Pax, Warszawa 1985.

Skierkowski M., Apologia Jezusa historycznego. Kilka uwag metodologicznych, „Znak” 2009, nr 647, http://www.miesiecznik.znak.com.pl/6452008ks-marek-skierkowskiapo logia-jezusa-historycznego-kilka-uwag-metodologicznych/. 